My Philosophy

And other Essays on the Moral and Political Problems of our Time. By Benedetto Croce. Selected by R. Klibansky, translated by E. F. Carritt. Pp. 240. (London: George Allen and Unwin, Ltd., 1949.) 15s. net.

BENEDETTO CROCE, the one Italian whom 1 Mussolini dared not silence and who was impervious to bribes and blackmail, is now well over eighty; but many of the essays in this book have been written quite recently. One on "Liberalism and Democracy" (No. 11 of the series) was actually published during the Nazi occupation, though in a learned journal which officials of the Gestapo were not likely to read of their own accord.

Three fairly long essays come first: "My Philosophy", where Croce explains his debt to Hegel and his difference from him; "The Moral Problem of Our Time", which is the old problem of how to combine liberty and order ; and "Why We Cannot Help Calling Ourselves Christians", an interesting avowal by a thinker who could never by any stretch be claimed as orthodox. The remaining thirty-four pieces are mostly short, some only a page or two. The bulk of them are political and, as might be expected, centre round the topic of liberty. Others deal with ethics and æsthetics, which for Croce are closely related subjects. Five are concerned with history and are the most difficult to follow. It is quite clear, though, that history for Croce is the product of the wills of human persons, not merely of impersonal forces or mass-movements. At the end are some pieces, headed "Various Thoughts", mostly quite short; the longest and most interesting is called "Soliloquy of an Old Philosopher". Here he comes back to his persistent theme, the interrelation of liberty and morality, and that, in spite of all setbacks in history, ideals are not extinguished. Perhaps it is meant to be Croce's valediction-one hopes not.

The translator has evidently done his work skilfully and carefully; but rather too many misprints have crept in.

A. D. R.

Kungl. Skogshögskolans Skrifter: Nr. 2-3

Tillväxtprognoser vid Skogsindelning : Två Problem (Prognosis of Increment for Calculation of Cutting), av Sven Petrini; Simplified Deduction of some Statistical Formulæ, by Sven Petrini. Pp. $12+$ 4. (Stockholm: Kungl. Skogshögskolan, 1949.) $1 \mathrm{kr}$.

TWO bulletins on statistics (Nos. 2 and 3), both by $\mathrm{S}$. Petrini, have recently been published, bound together in one volume, by the Royal School of Forestry, Stockholm. In the first, the author discusses estimation of growth increments in forests, by extrapolation from knowledge of the growth that has taken place during past years. He points out the serious danger that biased estimation will result from the common practice of assuming a linear rate of increase. In the latter part of the paper, the bias produced by natural deaths among the trees is considered.

The formulæ considered in "Simplified Deduction of some Statistical Formulæ" are those for the standard deviations of sums and products of statistical variates. The derivation of the formulæ may be simple, and the results are in the main correct, but the theory on which they are made to rest is entirely unsound. The correct formula for the standard error of a weighted average is stated to be wrong, and is replaced by a formula which may easily be seen to be quite incorrect. It is surprising that faulty proofs and erroneous statements on questions of so elementary a character should be published in the official bulletin of an institution of high repute.

D. J. Finney

\section{Gall Midges of Economic Importance}

By Dr. H. F. Barnes. (Agricultural and Horticultural Series.) Vol. 6 : Gall Midges of Miscellaneous Crops. Pp. $230+14$ plates. (London: Crosby Lockwood and Son, Ltd., 1949.) 15s. net.

7 THE latest volume of Dr. H. F. Barnes's comprehensive series on the gall midges deals with those which infest such miscellaneous crops as bamboos, basket willows, plants which serve as the source of beverages, dyes, textile fibres, sugar, spices, rubber and insecticides, together with medicinal and culinary herbs. The most substantial section is that which describes the midges of basket willows, on which the author has already published much original work. As Mr. A. Roebuck points out in a characteristic foreword, Dr. Barnes maintains an admirable balance between the point of view of the entomologist and of the grower.

The interest and value of the book is greatly enhanced by the introductory notes on the character and uses of the divers crops. An appendix by $\mathrm{Mr}$. H. C. H. Newton describes preliminary experiments in which it was shown that the midges which attack willows are repelled by their normal host plants if these are smeared with extracts from the 'immune' species of Salix, whereas there is no attraction to the immune species if these are smeared with extracts from susceptible varieties. As with earlier volumes, there are excellent indexes to the midges and the plants, and a general subject index. V. B. W.

\section{Bird Portraits}

A Book of Sketches and Paintings, with a Com. mentary. By J. C. Harrison. Pp. 119 (16 plates). (London: Country Life, Ltd., 1949.) 63s. net.

IR. J. C. HARRISON is well known as a skilled bird artist, and this volume of "Bird Portraits" from his brush and pencil will enhance his already considerable reputation. It includes some lovely pictures in colour and a number of pencil sketches. The latter are particularly fascinating; for example, the kingfisher plate, whereon this brilliant fisherman is shown in a variety of poses and caught in mid-dive. Although these pencil sketches are but black-andwhite work, the artist has captured the effect of iridescent colour, and we feel the bird's flashing beauty emanating from the page.

The drawings of various ducks are also attractive, especially those of sheldrake and long-tailed duck. Mr. Harrison shows us the sheldrake from fluffy white-and-black ducklings to maturity, and has well caught the somewhat goose-like character of the species. His colour plate of five sheldrake rising from the sand-dunes, to fly out over the shore, towards the incoming waves of a quiet sea, is one of the most charming of his colour illustrations; indeed, it pleased me best of all.

This volume is, of course, a picture book; but the paintings and sketches are supplemented by interesting notes, in which the artist tells us of his experiences and observations when sketching in the field. In conclusion, it only remains to say that every lover of bird life will enjoy this volume. Frances PITT 